\title{
Soundtracking Germany: Popular Music and National Identity
}

Melanie Schiller

London and New York: Rowman and Littlefield International, 2018

ISBN number $9781786615961(\mathrm{~PB})$

\section{Giacomo Bottà}

University of Helsinki

giacomo.botta@helsinki.fi

In 1996, the German band Tocotronic won the 'Jung, Deutsch und auf dem Weg nach oben' (young, German and on the way up) prize at the Comet Music Awards. Live on the music TV channel Viva, bass player Jan Müller laconically refused the prize and declared at the microphone that the band was neither proud to be young, nor to be German, and quickly left the stage. The band from Hamburg sang in German and was among the most well-known 'alternative' acts in the Federal Republic. Once confronted by success and by the 'German' label, Tocotronic reacted with a controversial action, revealing a somewhat anxiety-ridden attitude towards their nationality.

It is clear from this vignette that German identity in popular music is somehow problematic and cannot be exhausted only by reflecting on national image, soft diplomacy, cultural export and political cohesion; research needs to approach the issue from an interdisciplinary, original and critical standpoint. Soundtracking Germany: Popular Music and National Identity does this.

The book examines the German identity in the Federal Republic from Stunde Null (1945) to reunification (1990) and the way this has been negotiated in popular music. National identity has been widely researched in popular music studies, ranging from the seminal writings of Simon Frith (1993) and Martin Cloonan (1999) to the Routledge Global Popular Music Series, which at the time of writing counts twenty-one edited volumes about individual nations and has just released a Made in Germany volume (Seibt, Ringsmut and Wickström 2020).

German popular music studies are a fragile kaleidoscope according to Jacke and Ahlers (2017), whose edited collection Perspectives on German Popular Music "reflects on the discipline and its history, and successfully attempts at adjusting

IASPM Journal vol.11 no.1 (2021) 
some of the past lacks, such as the absence of attention towards the mainstream" (Bottà 2017, p. 62). Julio Mendívil (2008) has taken Schlager seriously in its subtle political and cultural dimension and offered an interesting take on its relation towards Heimat. East-German punk (Mohr 2018), West-German post-punk (Teipel 2001) and post-1989 techno (Denk and Von Thülen 2013) have been widely discussed in oral histories and studies, reflecting on music cultures in their national dimension. Research is also being currently conducted on the relation between popular music and populism in Germany.

Schiller takes a challenging and original path, first of all in the attempt to examine popular music and national identity through just five songs (plus one): "Wir sind die Eingeborenen von Trizonesien", The Lords' "Poor Boy", Kraftwerk's "Autobahn", D.A.F.'s "Der Mussolini", and Paul van Dyk and Peter Heppner's "Wir sind Wir", while Rammstein's "Mein Land" is used in the introduction to provide a setting for the rest of the book and in the conclusions to attest the ambiguity of national narrations. (1)

Each song is dissected in a dedicated chapter, moving forward from an understanding of popular music as an industry and epitomizing it "as an important cultural sphere in which identities are affirmed, challenged, taken apart, and reconstructed" (p. 5). Building on the work of Edward Said and Homi Bhabha, Schiller dissects German national identity as a ternary temporality, based on metaphoric (fixated upon the past and working at totalizing and fixing national identity), metonymic (based on everyday negotiations in the present) and melancholic (traumatic conflation of past and present) modes.

Moreover, the author does not take a mere sociological or musicological approach and adopts an interdisciplinary lens on music and society, which is not afraid to apply media studies, psychoanalysis and close reading. With a limited corpus of individual songs, Schiller opens up lyrics, music, meanings and representations. She extrapolates and magnifies microelements that become keys to understand and make sense of the macroscopic German geopolitics.

One of the key aspects of this book is its theoretical coherence. There are elements, which reoccur and are continuously enriched by theoretical nuances and interpretations. One of these is the notion of absence. It is first and foremost a spatial absence, as in the case of "Wir sind die Eingeborenen von Trizonesien", a carnival number articulating a surrogate national anthem for a surrogate divided nation. It is however also a sonic absence, which the author identifies for instance in the hi-hat ghastly skipping a beat in "Poor Boy" and in the refusal to talk about Hitler by the parents of Amon Düül II's Renate Knaup. "Der Mussolini" becomes an instrument to make sense of how to queer the tabooed and therefore absent past, destabilizing its meaning on the dance-floor. It is also a racial absence; once techno is assimilated as a German project, it is whitewashed and becomes worryingly sinister in some of its social and political use. As a reader, I missed in the book female musicians: what is the role of this absence in the canon of German music as a whole?

The chronological order of the songs allows an interesting media reading. In the "Trizonesien song", a pop song means basically lyrics to be collectively sung in a carnival Sitzung (convention), maybe swinging side-wards while sitting down on benches. Song by song, we see the pop song enriching itself, as a medium, at least in technological terms: through found sounds and attention towards visuals in the case of "Autobahn", through broken automation in the case of "Der Mussolini" until becoming a complex multimedia in the music videos of "Wir sind Wir" and "Mein Land", where meanings are layered in visual, aural and textual elements. 
The book offers a well-researched analysis of how German popular music has continuously mirrored and at the same time pushed the limits of what German identity could be, within the sometimes peaceful and sometimes tumultuous political history of the German Federal Republic. Writing and performing popular music about national identity doesn't mean normalizing it. On the contrary, this action reveals the complex, trauma-ridden and ever-changing meanings and values hidden behind a flag, a border, a language and a passport.

\section{Endnotes}

(1) The songs are collected in a Spotify playlist: https://open.spotify.com/playlist/ 73bgDAbbUtNMkmf9pcDXqT)

\section{References}

Ahlers, M. and Jacke C. 2017. Perspectives on German Popular Music. London and New York: Routledge.

Bottà, G. 2017. REVIEW I Perspectives on German Popular Music. Michael Ahlers and Christoph Jacke Eds. London and New York: Routledge, 2017 ISBN: 9781472479624 (HB). IASPM Journal 7 (2), 62 - 64. https://doi.org/10.5429/ 2079-3871(2017)v7i2.12en

Cloonan, M. 1999. Pop and the Nation-State: Towards a Theorisation. Popular Music 18 (2): 193-207. https://doi.org/10.1017/S0261143000009041

Denk, F. and Von Thülen, S. 2013. Der Klang der Familie. Berlin, Techno und die Wende. Franfkurt and Berlin: Suhrkamp.

Frith, S. 1993. Popular Music and the Local State. In T. Bennett et al. Ed. Rock and Popular Music: Politics, Policies, Institutions. London: Routledge: 15-24.

Mendívil, J. 2008. Ein musikalisches Stück Heimat: Ethnologische Beobachtungen zum deutschen Schlager. Bielefeld: Transcript.

Mohr, T. 2018. Burning Down the Haus: Punk Rock, Revolution, and the Fall of the Berlin Wall. Chapel Hill and New York: Algonquin Books.

Seibt, O., Ringsmut, M. and Wickström, D. 2020. Made in Germany: Studies in Popular Music. London and New York: Routledge.

Teipel, J. 2001. Verschwende deine Jugend. Frankfurt: Suhrkamp. 